Original Article

\title{
Antimicrobial and insecticidal effects of essential oil and plant extracts of Myrcia oblongata DC in pathogenic bacteria and Alphitobius diaperinus
}

\author{
Aplicação de óleo e extratos de Myrcia oblongata DC em bactérias patogênicas e \\ controle biológico de Alphitobius diaperinus
}

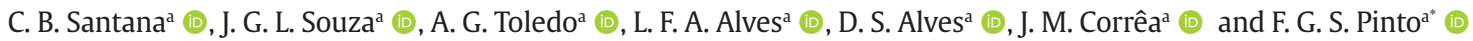 \\ aNatural Resources Conservation and Management Program, Microbiology and Biotechnology Laboratory (LAMIBI), State University of Western \\ Paraná- UNIOESTE. Cascavel, PR, Brasil
}

\begin{abstract}
The secondary metabolism products of plants have influenced great economic interest, given their chemical diversity and biological activities. Because of this, this study evaluates the phytochemical composition, antimicrobial activity, insecticidal, and antioxidant activity of plant extracts and oil of Myrcia oblongata. Saponins, steroids, triterpenoids, tannins, and flavonoids were detected. The extracts showed antimicrobial capacity on the tested microorganisms, except for the methanolic extract, which showed no activity for $P$. mirabilis and $S$. enteritidis. Regarding the analysis of antioxidant compounds, the hexanic, ethyl acetate and acetone extracts showed higher antioxidant activities and also higher insecticidal performance on Alphitobius diaperinus larvae, resulting in $80 \%$ adult mortality. The results reported here show that there may be a relationship between antioxidant potential and the insecticidal effect of Myrcia oblongata DC. The components present in both the extract and the oil can be used as natural alternative to synthetic compounds in the biological control of parasites and pathogenic microorganisms.
\end{abstract}

Keywords: antioxidant, phytochemistry, Salmonella, insecticide.

\begin{abstract}
Resumo
Os produtos do metabolismo secundário das plantas têm despertado grande interesse econômico, dada sua diversidade química e atividades biológicas. Neste sentido, o estudo objetivou avaliar a composição fitoquímica, atividade antimicrobiana, inseticida e antioxidante dos extratos vegetais e óleo de Myrcia oblongata. Foram detectados a presença de saponinas, esteróides, triterpenóides, taninos e flavonóides. Os extratos apresentaram capacidade antimicrobiana sobre os microrganismos testados, exceto o extrato metanólico que não demonstrou atividade para P. mirabilis e S. Enteritidis. Quanto a análise de compostos antioxidantes observou-se que os extratos hexânico, acetato de etila e acetona apresentaram maiores atividades antioxidantes e também maior performance inseticida sobre a larva Alphitobius diaperinus e exibindo mortalidade de $80 \%$ na fase adulta. Os resultados aqui reportados mostram que pode haver uma relação entre potencial antioxidante e efeito inseticida do óleo de Myrcia oblongata; os componentes presentes tanto no extrato como o oléo podem ser utilizados como alternativa natural aos compostos sintéticos no controle biológico de parasitas e microrganismos patogênicos.
\end{abstract}

Palavras-chaves: antioxidante, fitoquímica, Salmonella, inseticida.

\section{Introduction}

With the increase of poultry productivity, the number of enteric diseases also increased, caused by bacteria, mainly of the Enterobacteriaceae family, which include the genus Salmonella (Netto et al., 2005). These bacterias, in particular, are of utmost importance to public health, as salmonellosis is responsible for high human mortality rates worldwide (Sánchez-Vargas et al., 2011). In addition, the dispersal of these bacteria in the environment is associated with the intensive production of food of animal origin, and poultry products stand out as the main carriers of this pathogen (D’Aoust and Maurer, 2007)

The problem of microbial resistance is increasing mainly due to the extensive and inadequate use of growth-promoting antibiotics in poultry National Health Surveillance Agency of the Ministry of Health - ANVISA, 2011. There is a significant increase in the frequency of antimicrobial resistant bacteria that were routinely used.

Another problem in the poultry sector is the frequent use of chemicals for control of pests such as Alphitobius

*e-mail: fabiana.pinto@unioeste.br

Received: January 27, 2020 - Accepted: October 13, 2020

This is an Open Access article distributed under the terms of the Creative Commons Attribution License, which permits unrestricted use, distribution, and reproduction in any medium, provided the original work is properly cited. 
diaperinus (Coleoptera:Tenebrionidae). These beetles are controlled with pyrethroids and organophosphates (Lambkin and Furlong, 2011). However, these and other products have some disadvantages such as selection for resistant populations, environmental and bird contamination, as well as the microbial resistance of bacteria present in some insects (Japp et al., 2010).

Beyond the antimicrobial and insecticidal activity of extracts and essential oils, knowing the antioxidant activity is of great importance, as some compounds isolated from plants can replace synthetic preservatives in products and industries. However, for this purpose it is necessary to know the active principle of extracts and essential oils, in addition to adverse effects such as toxicity and chemical composition of these products (Melo et al., 2006).

Because of this, studies of this overview, work for therapeutic, prophylactic and alternative uses of these chemical compounds is of recognized importance (Vieira da Silva et al., 2016), and in this direction, plant extracts and essential oils stand out for their efficiency worldwide. In Brazil, the exploration of biological activity of plant chemicals has proven to be an efficient and more sustainable way to control zoonoses and decrease microbial resistance indices (Pandini et al., 2015; Weber et al., 2014).

In this context, the importance of exploring the antimicrobial, antioxidant, and insecticidal potential of plant bioactives, as well as the identification of their chemical constituents, increases. This research was divided into four experiments with the purpose of identify the phytochemical classes present in the plant extracts of Myrcia oblongata DC., and evaluated their antimicrobial activity against eleven standard bacteria and one yeast. Additionally to the activity of the essential oil and extracts on ten serotypes of Salmonella spp. of poultry importance were analyzed, the antioxidant activity was verified, and the insecticidal activity of the essential oil and plant extracts on the larvae and adults of $A$. diaperinus was evaluated.

\section{Materials and Methods}

\subsection{Collection and identification of plant material}

The leaves of $M$. oblongata were collected during the autumn season at the Paulo Gorski Ecological Park, from an Atlantic Forest biome located in the city of Cascavel in

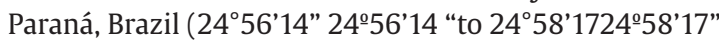
S, 532 $25^{\prime} 1453^{\circ} 25^{\prime} 14$ “a $53^{\circ} 27^{\prime} 06^{\prime}$ "W). The species had its identity confirmed and specimens deposited in the Herbarium of the State University of Western Paraná (UNOP) (UNOP voucher 1816).

The leaves were oven-dried at $40^{\circ} \mathrm{C}$ and processed in a Wiley knife mill with a $0.42 \mathrm{~mm}$ grain size. The obtained powder was stored in glass containers protected from light and humidity in a temperature-controlled $\left(27^{\circ} \mathrm{C}\right)$ room until the preparation of the plant extracts and the extraction of the essential oil (Ceyhan et al., 2012; Weber et al., 2014).

\subsection{Obtaining the essential oil}

According to the methodology proposed by Weber et al., (2014), M. oblongata dry plant material (140 g) was added to $1,400 \mathrm{~mL}$ of distilled water. The solution was placed in a Clevenger apparatus following the steamdragging distillation methodology for approximately $3 \mathrm{~h}$ at $100^{\circ} \mathrm{C}$. The obtained oil was stored in a freezer at $4{ }^{\circ} \mathrm{C}$ until use.

\subsection{Obtaining extracts}

To obtain the plant extracts, the dried and shredded leaves $(20 \mathrm{~g})$ were submitted to extraction on a shaker rotary shaker at $170 \mathrm{rpm}$ for $24 \mathrm{~h}$. The following extracting agents (100 mL) were used: distilled water, methanol $(\mathrm{MeOH})$, ethanol (EtOH), ethyl acetate (AcEt), acetone $(\mathrm{AcOH})$ and hexane (Hex). The obtained mixture were filtered on Whatman $\mathrm{N}^{\mathrm{o}} 1$ filter papers and centrifuged at 3,800 rpm for 15 minutes. After collecting the supernatant, except for the aqueous extract, the liquid phases were concentrated in a rotary evaporator to remove the solvent. All extracts were stored at $4^{\circ} \mathrm{C}$.

For the aqueous extract, the dried and ground leaves (20 g) were added to distilled water $(100 \mathrm{~mL})$; this mixture was kept on a rotary shaker at $220 \mathrm{rpm}$ for $24 \mathrm{~h}$. This solution was filtered on Whatman № 1 and centrifuged at 5,000 rpm for 15 minutes. Extracts of $\mathrm{MeOH}, \mathrm{EtOH}, \mathrm{AcEt}$, $\mathrm{AcOH}$, and Hex were prepared similarly to aqueous extracts, but after the supernatant collection, the extracts were rotated and evaporated. All extracts were stored at $4{ }^{\circ} \mathrm{C}$.

\subsection{Phytochemical prospecting}

Phytochemical assays for detecting the presence of steroids, triterpenoids, tannins, alkaloids, coumarins, saponins, anthocyanins, and flavonoids were performed according to the methodology developed by Matos (1997).

\subsection{Antimicrobial activity}

Antimicrobial activity was performed according to the methodology proposed by Weber et al. (2014) and Pandini et al. (2015) with modifications. Bacteria obtained from the International Bank were used: Escherichia coli (ATCC 25922), Salmonella enteritidis (ATCC 13076), Pseudomonas aeruginosa (ATCC 27853), Proteus mirabilis (ATCC 25933), and Klebsiella pneumoniae (ATCC 13883). Staphylococcus epidermidis (ATCC 12228), Staphylococcus aureus (ATCC 25923), Enterococcus faecalis (ATCC 19433), and Candida albicans yeast (ATCC 10231). In addition, Salmonella allinarum was obtained from the Adolfo Lutz Institute (IAL) and Bacillus subtillis was obtained from the culture collection of the Cefar Diagnostic Clinical Microbiology Laboratory located in São Paulo, SP, Brazil (CCCD-B005). In addition, ten serotypes of Salmonella spp. occurring in the western region of Paraná, Brazil (Pandini et al., 2015), were isolated from different aviaries in the region, and supplied by MercoLab Laboratories Ltda: S. Albany. These were S. braenderup, S. gafsa, S. heidelberg, S. idikan, S. lexington, S. livingstone, S. montevideo, S. saintpaul and S. senftenberg. 
All microorganisms were recovered in Brain Heart Infusion (BHI) enrichment broth and incubated for $24 \mathrm{~h}$ at $37^{\circ} \mathrm{C}$. The final bacterial concentrations were standardized to $1 \times 10^{6} \mathrm{CFU} / \mathrm{mL}$ and $1 \times 10^{5} \mathrm{CFU} / \mathrm{mL}$ yeast in saline at $0.85 \%$.

For the Minimum Inhibitory Concentration (MIC) test, the essential oil was diluted to a concentration of $7000 \mu \mathrm{g} / \mathrm{mL}$. For this, a $70 \mathrm{mg}$ aliquot of the oil was diluted with $1 \mathrm{~mL}$ methanol (10\%). From this solution $500 \mu \mathrm{L}$ were homogenized in $4.5 \mathrm{~mL}$ Muller-Hinton (MH) broth. The plant extracts were diluted as follows: to $0.40 \mathrm{~g}$ of extract, $1 \mathrm{~mL}$ of methanol P.A and $1 \mathrm{~mL}$ of MH broth $(2 \times$ concentration $)$ were added. The aqueous extract was used directly in the wells with $150 \mu \mathrm{L}$ MH broth.

The MIC for both oil and extracts were performed according to the standards of the Clinical and Laboratory Standards Institute - CLSI (2007). For dilutions with essential oil, we proceeded as follows: in 96 well microdilution plates $150 \mu \mathrm{L}$ of diluted MH broth (in all wells) and $150 \mu \mathrm{L}$ of the essential oil solution (previously prepared) were added. Serial dilutions from 7.000 to $3.4 \mu \mathrm{g} / \mathrm{mL}$ were performed in the posterior wells. For the extracts, the extract solution, methanol and MH broth (previously prepared) were added to the first well of each row at a concentration of $200 \mathrm{mg} / \mathrm{mL}$, in the subsequent wells $150 \mu \mathrm{L}$ of $\mathrm{MH}$ broth (double concentration) was added, and serial dilutions ranging from $200 \mathrm{mg} / \mathrm{mL}$ to $3.12 \mathrm{mg} / \mathrm{mL}$ were performed. To each well was added $10 \mu \mathrm{L}$ of the previously diluted microorganism inoculum. The plates were slightly homogenized and incubated for $24 \mathrm{~h}$ at $37^{\circ} \mathrm{C}$. The MIC was performed in triplicate.

After the incubation period, $10 \mu \mathrm{L}$ of $1 \%$ triphenyl tetrazolium chloride (TTC) solution was added to each well of the microplates, and they were incubated for a further three hours at $37^{\circ} \mathrm{C}$. The presence of red staining in the wells was interpreted as evidence of a negative inhibitory effect of the essential oil or plant extract, while the absence of staining was considered positive proof of the inhibitory action; that is, the essential oil or the plant extract did not inhibit the growth of microorganisms present in the microplates.

As a positive control, $30 \mathrm{mg} / \mathrm{mL}$ gentamicin solution was used for bacteria and nystatin for $C$. albicans yeast. A control with methanol was also performed; to this were added $70 \mu \mathrm{L} \mathrm{MH}$ broth, $70 \mu \mathrm{L} 10 \%$ methanol and $10 \mu \mathrm{L}$ of the microorganisms tested.

Before TTC was added to the wells, $10 \mu \mathrm{L}$ of the solution from each well, including controls, were removed and inoculated into $\mathrm{MH}$ Agar Petri dishes for the Minimum Bactericidal Concentration (MBC) or Minimum Fungicidal Concentration (MFC) test. The plates were incubated for $24 \mathrm{~h}$ at $37^{\circ} \mathrm{C}$.

$\mathrm{MIC}$ and $\mathrm{MBC}$ of the essential oil were classified according to the criteria proposed by (Sartoratto et al., 2004), with the activity considered low $(7000-3500 \mu \mathrm{g} / \mathrm{mL})$, moderate $(1700-875 \mu \mathrm{g} / \mathrm{mL})$, high $(437.5-218.75 \mu \mathrm{g} / \mathrm{mL})$ or very high $(<109.375 \mu \mathrm{g} / \mathrm{mL})$. For the extracts the classifications were considered high $(<12.5 \mathrm{mg} / \mathrm{mL})$, moderate (12.5-25 mg/mL), low (50-100 mg/mL), and very low (> $100 \mathrm{mg} / \mathrm{mL}$ ) (Araújo, 2010).

\subsection{Antioxidant activity}

The antioxidant activity of the essential oil was measured according to the free radical reduction method using 2,2-diphenyl-1-picryl hydrazole (DPPH) (Scherer et al., 2009; Weber et al., 2014). For this, $0.1 \mathrm{~mL}$ aliquots of the plant extracts, at a concentration of $200 \mathrm{mg} / \mathrm{mL}$ were treated with $3.9 \mathrm{~mL}$ of $50 \%$ methanolic solution and homogenized in a tube shaker. The absorbances of the samples were measured by a spectrophotometer at $515 \mathrm{~nm}$. As negative control, a solution composed of methanol, acetone, and water ( $40 \mathrm{~mL}$ of $70 \%$ acetone solution, $40 \mathrm{~mL}$ of $50 \%$ methanol solution, and $20 \mathrm{~mL}$ of distilled water) was added with the addition of the DPPH radical. The positive control was the commercial synthetic butyl hydroxy toluene (BHT) antioxidant. As blank 50\% methanol was used for spectrophotometer calibration. DPPH absorbances at concentrations of 34, 64, 100, 134, 166 and $200 \mu \mathrm{m}$ (readings: $\lambda=515 \mathrm{~nm}$ ) were used to determine a linear data dispersion function (of DPPH absorbances).

Antioxidant activity calculations were performed as follows: initially the equation of the DPPH line (linear function) was calculated. DPPH reduction indices for plant extracts and BHT (positive control) were calculated by the equation: \% [(Abs0 - Abs 1$) / A b s 0] \times 100$, where Abs0 is the absorbance of the negative control and Abs 1 is the absorbance of sample. The $\mathrm{IC}_{50}$, which is the concentration of oil/plant extract required to reduce $50 \%$ of the DPPH free radical, was calculated through the absorbances of the different DPPH concentrations, which generated a linear function. The absorbance values were evaluated by the analysis of variance (ANOVA) test, with a significance level of 0.05 , followed by the Tukey test for comparison of means. Statistical analysis was performed using the statistical software $\mathrm{R}^{\circledR}$ version 3.3.2.

\subsection{Insecticidal activity of essential oil and plant extracts of M. oblongata on A. diaperinus larvae and adults}

The experiment was based on Marcomini et al. (2009) with modifications. The insects were collected in a broiler poultry house in Cascavel, Paraná, Brazil and kept in the laboratory for $24 \mathrm{~h}$ before being used in biological assays. Two bioassays were conducted to determine the toxicity of the treatments on the young phase, in which larvae with $1 \mathrm{~cm}$ length were used, and for the adult phase of A. diaperinus.

Plant extracts (AcEt, $\mathrm{AcOH}, \mathrm{MeOH}, \mathrm{EtOH}$, and $\mathrm{Hex}$ ) were solubilized in acetone to concentrations of 10,5 , 2.5 , and $1.25 \%$. Then aliquots of the acetone-solubilized extracts were further diluted using $0.1 \%$ Tween $80^{\circledR}$ aqueous solution. For the tests using the essential oil, the acetone was diluted to $10,5,2.5$, and $1.25 \%$.

In both bioassays, the control treatment used sterile distilled water and $0.1 \%$ Tween $80^{\circledR}$ (in the same proportion as the extracts) and $10 \%$ acetone. The assays were performed on glass plates (diameter: $7 \mathrm{~cm}$ ) with Whatman № 1 filter paper1 (diameter: $5 \mathrm{~cm}$ ) and the larvae and adults of $A$. diaperinus were fed $1 \mathrm{~g}$ of wheat straw. Based on the methodology of Marcomini et al. (2009) different concentrations of essential oil and extracts of $M$. oblongata were added to the Petri dishes, and A. diaperinus larvae and adults walked for 30 seconds in this material (Marcomini et al., 2009). Mortality assessment was performed 24 hours after oil and extract application; 
Insects that did not respond to touch with tweezers were considered dead. Five repetitions were performed for each extract and concentration of essential oil.; insects that did not respond to touch with forceps were considered dead. Five repetitions were performed for each extract and essential oil concentration.

The results underwent a nonparametric Kruskal-Wallis statistical test and Dunn's follow-up test for independent sample comparisons after normality and homoscedasticity assumptions were analyzed ( $\alpha=0.05 \%$ ).

\section{Results}

\subsection{Phytochemical Prospecting}

In the determination of the phytochemistry of the leaves of $M$. oblongata, it was possible to verify groups of compounds from the secondary metabolism of the plants, such as saponins, steroids, triterpenoids, tannins, and flavonoids. The aqueous extract showed the presence of saponins and tannins; in the extracts Hex, AcEt, and $\mathrm{AcOH}$ there were steroids, triterpenoids, and tannins. The EtOH and $\mathrm{MeOH}$ extracts showed only the presence of triterpenoids (Table 1)

\subsection{Antimicrobial activity}

The extracts of $M$. oblongata showed antimicrobial activity for all microorganisms tested, except for the $\mathrm{MeOH}$ extract, which did not have bactericidal activity for P. mirabilis and S. enteritidis (Table 2).

The MIC and MBC of M. oblongata essential oil ranged from 437.5 to $7000 \mu \mathrm{g} / \mathrm{mL}$ for the ten salmonella serotypes tested (Table 3 ). The best activities were verified on the serotypes $S$. Lexington and S. Saintpaul with CIM 437.5/ MBC 3,500 and 875/1,750, respectively. Plant extracts showed activity on all Salmonella spp. evaluated, ranging from 1.57 to $100 \mathrm{mg} / \mathrm{mL}$.

\subsection{Antioxidant activity}

The absorbances of the free radical DPPH resulted in the linear function (Equation 1 ) with $\mathrm{R}^{2}=0.9233$, which was achieved by $\mathrm{IC}_{50}$ calculations (Table 4 ).

$$
\mathrm{y}=0.0139 \mathrm{x}-0.138
$$

By the analysis of variance test (ANOVA), with a significance level of 0.05 , it was found that at least one of the mean absorbances of the six extracts is different $(p<0.05 ; G L=6)$. The means of extracts $\mathrm{HeOH}$ and AcEt did not differ from BHT (positive control) by Tukey test (Table 4). These two extracts showed activity higher than $80 \%$. The $\mathrm{EtOH}, \mathrm{MeOH}$, and aqueous extracts did not show antioxidant activity; that is, there was no reduction of significant absorbances in the reading on the spectrophotometer, presenting DPPH sequestration percentage below $30 \%$.

\subsection{Insecticidal activity of essential oil and plant extracts of M. oblongata on A. diaperinus larvae and adults}

The experiment to evaluate insecticide activity showed that, for $A$. diaperinus larvae, there was a statistical difference between the medians of the treatments by Kruskal-Wallis ( $\mathrm{p}<0,0 ; 5$; Kruskal-Wallis chi-squared $=26.63 ; \mathrm{GL}=24$ ). The best mortality rate was $97.75 \%$ for the EtOH extract, followed by $95.25 \%$ for the essential oil. AcEt and $\mathrm{MeOH}$ extract did not differ by the Dunn test for independent sample comparisons $(\alpha=0.05 \%)$ and showed $87.75 \%$ and $86.5 \%$ lethality, respectively. EtOH (78.5\%) and $\mathrm{AcOH}(59.8 \%)$ had the lowest mortality rates. There was no mortality for the aqueous extract (Table 5).

A. diaperinus adults showed different mortality responses between treatments by the test Kruskal-Wallis ( $p<0,05$; Kruskal-Wallis chi-squared = 28.117; GL = 24). There was a large range in the Coefficient of Variation for adults due to the large difference in mortality between treatments. The best fatality rate was for essential oil (92.5\%). The other extracts had mortality below 20\%: $\mathrm{MeOH} 19.75 \%$, AcEt 19.25\%, Hex 13.25\%, AcOH 6.5\%, and EtOH 2.25\% (Table 6). There was no mortality for the aqueous extract.

\section{Discussion}

In the phytochemical prospecting saponins, steroids, triterpenoids, tannins, and flavonoids were identified

Table 1. Classes of secondary metabolites identified in the extracts of M. oblongata.

\begin{tabular}{|c|c|c|c|c|c|c|}
\hline \multirow{2}{*}{$\begin{array}{c}\text { Metabolite } \\
\text { Classes }\end{array}$} & \multicolumn{6}{|c|}{ Extracts of $M$. oblongata } \\
\hline & Aqueous & EtOH & МeOH & AcEt. & AcOH & Hex \\
\hline Saponins & + & - & - & - & - & - \\
\hline Steroids & - & - & - & + & + & + \\
\hline Triterpenoids & - & + & + & + & + & + \\
\hline Alkaloids & - & - & - & - & - & + \\
\hline Tannins & + & - & - & + & + & + \\
\hline Coumarins & - & - & - & - & - & - \\
\hline Anthocyanins & - & - & - & - & - & - \\
\hline Flavonoids & - & - & - & + & - & + \\
\hline
\end{tabular}

+ Presence of the compound; - absence of compound. MeOH: methanol extract; EtOH: ethanol extract; AcEt: ethyl acetate; AcOH: acetone extract and Hex: hexane extract. 
Table 2. Minimum Inhibitory Concentration (MIC), Minimum Bactericidal Concentration (MBC), and Minimum Fungicidal Concentration (MFC) of M. oblongata plant extracts against standard microorganisms.

\begin{tabular}{|c|c|c|c|c|c|}
\hline \multirow{2}{*}{ Microorganisms } & \multicolumn{5}{|c|}{ Extracts CIM/MBC } \\
\hline & Hex & $\mathrm{MeOH}$ & EtOH & AcEt & AcOH \\
\hline \multicolumn{6}{|c|}{ Gram-negative } \\
\hline E. coli & $50 / 100$ & $50 / 50$ & $100 / 100$ & $50 / 100$ & $6.25 / 25$ \\
\hline P. aeruginosa & $25 / 100$ & $25 / 100$ & $50 / 100$ & $100 / 100$ & $12.5 / 100$ \\
\hline P. mirabilis & $25 / 50$ & $100 /-$ & $25 / 100$ & $50 / 200$ & $1.56 / 25$ \\
\hline K. pneumoniae & $50 / 100$ & $12.5 / 25$ & $12.5 / 100$ & $12.5 / 50$ & $12.5 / 100$ \\
\hline S. Enteritidis & $50 / 200$ & $50 /-$ & $50 / 100$ & $6.25 / 50$ & $25 / 100$ \\
\hline S. Gallinarum & $50 / 100$ & $50 / 100$ & $100 / 200$ & $50 / 100$ & $100 / 200$ \\
\hline \multicolumn{6}{|c|}{ Gram-positive } \\
\hline S. epidermidis & $12.5 / 50$ & $12.5 / 12.5$ & $6.25 / 25$ & $6.25 / 25$ & $3.125 / 12.5$ \\
\hline S. aureus & $25 / 50$ & $12.5 / 50$ & $12.5 / 50$ & $3.125 / 50$ & $6.25 / 12,5$ \\
\hline E. faecalis & $25 / 100$ & $6.25 / 50$ & $50 / 100$ & $3.125 / 25$ & $3.125 / 12.5$ \\
\hline B. subtillis & $25 / 50$ & $25 / 100$ & $50 / 100$ & $25 / 25$ & $12.5 / 25$ \\
\hline \multicolumn{6}{|c|}{ Yeast cells } \\
\hline C. albicans & $12,5 / 25$ & $50 / 100$ & $100 / 100$ & $25 / 100$ & $25 / 100$ \\
\hline
\end{tabular}

High: <12.5 mg/mL; Moderate: $12.5-25 \mathrm{mg} / \mathrm{ml}$; low: 50-100 mg/mL; very low:> $100 \mathrm{mg} / \mathrm{mL}$; -:Not detected; MeOH: methanol extract; EtOH ethanol extract; AcEt: ethyl acetate; AcOH: acetone extract and Hex: hexane extract.

Table 3. Minimum Inhibitory Concentration (MIC) and Minimum Bactericidal Concentration (MBC) of M. oblongata plant extracts and essential oil against different Salmonella spp serotypes.

\begin{tabular}{ccccccc}
\hline \multirow{2}{*}{ Microorganisms } & \multicolumn{5}{c}{ Extracts CIM/MBC } \\
\cline { 2 - 7 } & Hex & MeOH & EtOH & AcEt & AcOH & OE \\
\hline S. Albany & $12.5 / 50$ & $100 / 100$ & $50 / 100$ & $25 / 50$ & $50 / 100$ & $3,500 / 7000$ \\
S. Braenderup & $6.25 / 50$ & $50 / 200$ & $12.5 / 100$ & $3.125 / 50$ & $25 / 50$ & $3,500 / 7000$ \\
S. Gafsa & $12.5 / 100$ & $100 / 200$ & $50 / 100$ & $25 / 200$ & $12,5 / 100$ & $1,750 / 3,500$ \\
S. Heidelberg & $12.5 / 50$ & $12.5 / 100$ & $25 / 100$ & $12.5 / 50$ & $12, ., 5 / 50$ & $3,500 / 7000$ \\
S. Idikan & $6.25 / 100$ & $100 /-$ & $100 / 100$ & $6.25 / 100$ & $25 / 200$ & $1,750 / 3,500$ \\
S. Lexington & $12,5 / 200$ & $100 / 100$ & $100 / 100$ & $50 / 200$ & $25 / 100$ & $437,5 / 3,500$ \\
S. Livingstone & $25 / 100$ & $100 / 200$ & $50 / 200$ & $6.25 / 50$ & $25 / 100$ & $3,500 / 3,500$ \\
S. Montevideo & $12.5 / 100$ & $100 / 100$ & $100 / 200$ & $12,5 / 100$ & $12.5 / 100$ & $3,500 /-$ \\
S. Saintpaul & $6,25 / 25$ & $50 / 100$ & $100 / 200$ & $1.5625 / 25$ & $6.25 / 100$ & $875 / 1,750$ \\
S. Senftenberg & $12.5 / 100$ & $25 / 100$ & $25 / 100$ & $12.5 / 50$ & $100 / 50$ & $3,500 / 7000$ \\
\hline
\end{tabular}

Extract activity ranges from: $200 \mathrm{mg} / \mathrm{mL}$ to $0.0976 \mathrm{mg} / \mathrm{mL}$. High Activity: $<12.5 \mathrm{mg} / \mathrm{mL}$; Moderate: $12.5-25 \mathrm{mg} / \mathrm{mL}$; low: $50-100 \mathrm{mg} / \mathrm{mL}$; very low:> $100 \mathrm{mg} / \mathrm{mL}$. Essential Oil Activity - Low: 7000-3500; Moderate: 1700-875; high: 437.5-218.75; very high: <109.3. Not detected: -. There was no activity for aqueous extracts. MeOH: methanol extract; EtOH ethanol extract; AcEt: ethyl acetate; AcOH: acetone extract; Hex: hexane extract and OE: essential oil.

in the plant extracts of M. oblongata. The extracts of $M$. oblongata showed activity for all microorganisms tested, except the $\mathrm{MeOH}$ extract, which did not show bactericidal activity for P. mirabilis or S. enteritidi. Hex, AcEt, and AcOH extracts showed similar antioxidant activity to BHT (positive control).

The essential oil and Hex extract presented the highest mortality rates, above $95 \%$, on $A$. diaperinus larvae. The best adult lethality rate for $A$. diaperinus was for essential oil (92.5\%).
The Myrtaceae family is widely studied for the production of secondary metabolites. The presence of tannins, steroids, and saponins in the leaves of Gomidesia affinis and Gomidesia spectabilis of this family has been demonstrated (Sakita and Aguiar, 2006). In addition, there are triterpenes, flavonoids, and alkaloids in extracts of Calycorectes psidiiflorus (Domingues et al., 2010) and tannins and flavonoids in Pimenta pseudocaryophyllus. These are all from the same family (Paula et al., 2008), for the genus Myrcia, we found in the literature reports 
Table 4. DPPH (2,2-diphenyl-1-picril hidrazil) index (\% reduction) and IC50 in different extracts of M. oblongata.

\begin{tabular}{cccc}
\hline Test Solution & Mean \pm standard desviation & \% reduction DPPH & IC $_{\mathbf{5 0}}$ \\
\hline BHT Positive Control & $0.4070 \pm 0.44 \mathrm{a}^{*}$ & 93.77 & 6.18 \\
Hexane & $0.2672 \pm 0.1 \mathrm{a} \mathrm{b}$ & 90.18 & 9.37 \\
Ethyl acetate & $0.4260 \pm 0.42 \mathrm{a} \mathrm{b} \mathrm{c}$ & 84.14 & 14.13 \\
Acetone & $0.5824 \pm 0.19 \mathrm{c}$ & 76.26 & 19.17 \\
\hline
\end{tabular}

*Values followed by the same letter do not differ from each other by the Tukey test.

Table 5. Mortality (\%) caused by M. oblongata essential oil and plant extracts on A. diaperinus larvae.

\begin{tabular}{|c|c|c|c|c|c|c|}
\hline \multirow{2}{*}{$\begin{array}{c}\text { Extracts/ } \\
\text { Essential Oil }\end{array}$} & \multicolumn{6}{|c|}{ Concentrations } \\
\hline & $1.25 \%$ & $2.5 \%$ & $5 \%$ & $10 \%$ & Witness & p-value \\
\hline AcEt & $87 \mathrm{bc}$ & $86 \mathrm{bC}$ & $83 \mathrm{cC}$ & $95 \mathrm{aC}$ & 0 & $<0.0005$ \\
\hline $\mathrm{AcOH}$ & $17.20 \mathrm{dE}$ & $74 \mathrm{bE}$ & $82 \mathrm{aE}$ & $66 \mathrm{cE}$ & 0 & $<0.0005$ \\
\hline $\mathrm{MeOH}$ & $70 \mathrm{cC}$ & $90 \mathrm{bc}$ & $90 \mathrm{bc}$ & $96 \mathrm{aC}$ & 0 & $<0.0005$ \\
\hline $\mathrm{EtOH}$ & 16bD & $98 \mathrm{aD}$ & $100 \mathrm{aD}$ & $100 \mathrm{aD}$ & 0 & $<0.0005$ \\
\hline Hex & $96 \mathrm{aA}$ & $97 a A$ & $99 \mathrm{aA}$ & $99 \mathrm{aA}$ & 0 & $<0.0005$ \\
\hline EO & $81 \mathrm{bB}$ & $100 \mathrm{aB}$ & $100 \mathrm{aB}$ & $100 \mathrm{aB}$ & 0 & 0.0923 \\
\hline p-value & $<0.0005$ & $<0.0005$ & $<0.0005$ & $<0.0005$ & & \\
\hline CV (\%) & & & & & & 3.14 \\
\hline
\end{tabular}

Lower case letters in the row and upper case letters in the column differ by Dunn's multiple comparison test ( $\alpha=0.05 \%)$ after the KruskalWallis test; CV: coefficient of variation; Average mortality in percentage. MeOH: methanol extract; EtOH ethanol extract; AcEt: ethyl acetate; $\mathrm{AcOH}$ : acetone extract; Hex: hexane extract, and OE: essential oil.

Table 6. Mortality (\%) caused by M. oblongata essential oil and plant extracts on A. diaperinus adults.

\begin{tabular}{|c|c|c|c|c|c|c|}
\hline \multirow{2}{*}{$\begin{array}{c}\text { Extracts/ } \\
\text { Essential Oil }\end{array}$} & \multicolumn{6}{|c|}{ Concentrations } \\
\hline & $1.25 \%$ & $2.5 \%$ & $5 \%$ & $10 \%$ & control & p-value \\
\hline AcEt & $8 \mathrm{bB}$ & $19 a \mathrm{~B}$ & $21 \mathrm{aB}$ & $29 \mathrm{aB}$ & 0 & $<0.0005$ \\
\hline $\mathrm{AcOH}$ & ObB & $2 \mathrm{bB}$ & $5 \mathrm{bB}$ & $19 \mathrm{aB}$ & 0 & $<0.0005$ \\
\hline $\mathrm{MeOH}$ & $9 \mathrm{bB}$ & $15 \mathrm{bB}$ & $22 \mathrm{aB}$ & $33 \mathrm{aB}$ & 0 & $<0.0005$ \\
\hline $\mathrm{EtOH}$ & $3 \mathrm{aC}$ & $1 \mathrm{aC}$ & $2 \mathrm{aC}$ & $3 \mathrm{aC}$ & 0 & $>0.0005$ \\
\hline Hex & $1 \mathrm{cB}$ & $5 c B$ & $16 \mathrm{bB}$ & $31 \mathrm{aB}$ & 0 & $<0.0005$ \\
\hline $\mathrm{OE}$ & $87 a A$ & $87 a A$ & $96 \mathrm{aA}$ & $100 \mathrm{aA}$ & 0 & $>0.0005$ \\
\hline p-value & $<0.0005$ & $<0.0005$ & $<0.0005$ & $<0.0005$ & & \\
\hline $\mathrm{CV}(\%)$ & & & & & & 58.76 \\
\hline
\end{tabular}

Lower case letters in the row and upper case letters in the column differ by Dunn's multiple comparison test ( $\alpha=0.05 \%$ ) after the KruskalWallis test; CV: coefficient of variation; Average mortality in percentages. MeOH: methanol extract; EtOH ethanol extract; AcEt: ethyl acetate; $\mathrm{AcOH}$ : acetone extract; Hex: hexane extract; and OE: essential oil.

of phenolic compounds in Myrcia bela (Saldanha, 2013), Myrcia hiemalis (Silva, 2007) and Myrcia rotundifolia (Cerqueira et al., 2009).

In studies with phenolic compounds, their antioxidant capacities have been demonstrated, as well as their possible effects in the prevention of several cardiovascular, cancerous, and neurological diseases. The beneficial action of phenolic compounds in human health has been related to their anti-inflammatory activity, and preventing the action of free radicals in the body (Pham-Huy et al., 2008).

Phenolic compounds such as steroids, triterpenoids, tannins and flavonoids have in their structure benzene groups and hydroxyl groups (Hernández Ángel and Prieto
González, 1999). Flavonoids are polyphenols, single or acid phenols, where hydrogen atoms of hydroxyl groups, double benzene ring bonds, and some flavonoids may confer biological activities (Silva et al., 2010; RiceEvans et al., 1997) as antioxidants and antimicrobials and insect repellents (Rosa et al., 2016; Rathi et al., 2008).

Flavonoids are present in some fruits and vegetables, and these are presented as flavonoids, flavones, flavanones, catechins, anthocyanins, isoflavones, and chalcones (Graham, 1992; Van-Acker et al., 1996). Non-flavonoids are derivatives of hydroxycinnamic and hydroxybenzoic acids, which may also have biological activities. These activities are related to the position of the hydroxyl groups and also 
to the proximity of the $-\mathrm{CO}_{2} \mathrm{H}$ group to the phenyl group (Silva et al., 2010).

The triterpenoids in the terpene group have diverse structures with over 40,000 different shapes. These different forms are present in plants, animals, and microorganisms and have many functions in the plant and animal kingdom and human health. These compounds are released when predators and pathogens attack; however, the biological role of several terpenoids are not yet known ((Arteaga et al., 2009; Gershenzon and Dudareva, 2007; Roberts, 2007).

Several studies have demonstrate the activity of plant extracts of members of the Myrtaceae family on different types of microorganisms. Ferreira and Vargas, (1999) indicated that in the S. typhimurium assay, Myrciaria tenella extract (Myrtaceae) showed mutagenic activity on this bacterium, probably due to the presence of flavonoids and tannins in the extracts. These compounds are also present in the extracts of M. oblongata. Extracts with different solvents of Psidium guajava showed antimicrobial activity on growth of E. coli, S. aureus, P. aeruginosa, P. mirabilis, K. pneumoniae, S. typhimurium, and Candida sp. (Carvalho et al., 2002; Chah et al., 2006; Nair and Chanda, 2007). In addition, the efficiency of Myrciaria cauliflora, P. guajava and Syzygium cumini extracts that showed activity by CIM and MBC/ MFC on C. albicans, E. coli, K. pneumoniae, P. aeruginosa, S. Typhimurium, S. aureus and B. subtilis have also been reported (Bona et al., 2014); In Boskovic et al. (2018) study, the ethanol extract of Anchusa officinalis was the best extract with antimicrobial activity.

The aqueous extract showed no activity for any microorganism tested (Tables 2 and 3). This result is similar to information reported by other authors who found no antimicrobial activity from aqueous extracts of P. guajava, M. cauliflora, and S. cumini (Myrtaceae) for C. albicans, E. coli, K. pneumoniae, B. subtilis, S. aureus, or S. typhimuriumS. Typhimurium, at a concentration of $400 \mathrm{mg}$. $\mathrm{mL}^{-1}$, by agar diffusion and microdilution methodologies (MIC and MBC) (Bona et al., 2014).

The antibacterial activity of the essential oil can be explained by the presence of the major compounds caryophyllene oxide (22.03\%), trans-verbenol (11.94\%) and $\delta$-pinene (6.65\%). As they are highly hydrophobic, these monoterpenes can interact with the cell membrane of microorganisms, causing significant damage to the plasma membrane and ultimately causing cell lysis (Turina et al., 2006). Burt (2004) states that the antimicrobial activity of essential oils is related to the synergistic effect of chemical constituents, which may have occurred with $M$. oblongata essential oil.

Plant extracts showed activity on all Salmonella spp. evaluated. Similar results were observed by Voss-Rech et al. (2011), where 20 Salmonella serotypes were tested against extracts of Eugenia jambolana, Eugenia uniflora, Caryophyllus aromaticus, and Psidium araca (Myrtaceae), and all presented MIC and MBC ranging from 40 to $240 \mathrm{mg}$ $\mathrm{mL}^{-1}$. The wide variation between the inhibitory effect may be related to the different metabolite groups present in the extracts (Raven, 2007).

There is a difficulty for methodological comparisons to evaluate antimicrobial activity, there is a difficulty in comparing the results obtained by different authors, since there are modifications in the methodologies used; that is, there is no one pattern followed. Variations occur from inoculum preparation method, dilutions, and reading results (Cavanagh and Wilkinson, 2002).

The antioxidant activity of Hex, AcEt, AcEt and $\mathrm{AcOH}$ extracts may be associated with the presence of phenolic compounds, especially tannins and flavonoids that have recognized antioxidant activities (Ali et al., 2011). The efficiency of these compounds is linked to hydrogen transfer that neutralizes the action of free radicals (Brewer, 2011). Flavonoids act as metal chelators, singlet oxygen deactivators, and consequently reduce free radicals (Carteler, 2005; Carvalho et al., 2002). Tannins are capable of intercepting active oxygen into stable radicals (Simões et al., 2004). The quantities of phenolic compounds vary due to different variables that affect the plants, such as climate, soil type, species, cultivar, temperature, pathogen attack, and the type of storage of leaves and plant extracts (Melo et al., 2008). In foods, phenolic compounds may contribute to oxidative stability (Castañeda-Ovando et al., 2009).

Extracts of twelve species of the Myrtaceae family: Blepharocalyx salicifolius, Eugenia bimarginata, Eugenia dysenterica, Eugenia klotzschiana, Hexachlamys edulis, Psidium australe, and Psidium laruotteanum and of the genus Myrcia: Myrcia bela, Myrcia tomyrcia and Myrentos lingua were tested against the free radical DPPH. They had $\mathrm{DPPH}$ and $\mathrm{IC}_{50}$ reduction percentage values similar or higher than Camellia sinensis (positive control), whose tea has high antioxidant activity due to the large amount of phenolic compounds (Takao et al., 2015). The aqueous extract of Lafoensia pacari (Myrtaceae) did not show significant antioxidant activity at a concentration of $400 \mu \mathrm{g} / \mathrm{mL}$ (Campos and Fransson, 2011). These data from the extracts of the Myrtaceae family and genus Myrcia are similar to those found for M. oblongata.

Results with mortality rates higher than $50 \%$ for extracts and oils of the Myrtaceae family were demonstrated by Eucalyptus citriodora essential oil on nematodes (Macedo et al., 2012). Eucalyptus grandis and Eucalyptus citriodora extracts also caused high lethality on the beetle Acanthoscelides obtectus (Mazzonetto and Vendramim, 2003).

Essential oils can act on digestive and essential oils can act on digestive, neurological enzymes or interact with the insect's integument (Isman, 2006). Kim et al., (2003) described the relationship between chemical structure and biological activity of compounds, noting that the greater the ability of a chemical compound to dissolve into fats, the greater the penetration of the insect integument. Prado (2007) pointed out that some compounds can act by contact; that is, they are absorbed by exoskeleton chitin or airways, presenting a fumigant action.

In this work, the essential oil promoted mortality higher than $80 \%$ for both larvae and adults at all concentrations tested (10, 5, 2.5 and $1.25 \%)$, possibly due to the substances present in the essential oil and the form of application. Myrcia oblongata oil presents as major compounds caryophyllene oxide, trans-verbenol, and $\delta$-pinene. These terpenes have repellency potential and proven mortality on coleopterans such as Sitophilus zeamais (Tapondijou et al., 2005) and Tribolium confusum (Lima et al., 2009). 
When analyzing the volatile constituents of Cyanea angustifolia, researchers when analyzing the volatile constituents of Cyanea angustifolia, they found 40 different types of terpenes, noting that these constituents are responsible for the inhibition of acetylcholinesterase in insects (Savaris et al., 2012). Such substances were also found in the M. oblongata phytochemistry. Pauliquevis and Favero (2015), analyzing different methods of application of the essential oil of Pothomorphe umbellata, found that it was efficient by the contact surface method on Sitophilus zeamais, a methodology similar to that used in this study with M. oblongata.

The insecticidal activity of members of the Myrtaceae family is proven. Eugenia uniflora and Melia azedarach $10 \%$ essential oil was tested on Atta laevigata and showed high mortality potential (Jung et al., 2013). Eugenia florida and Eugenia handroana (Myrtaceae) extracts reduced the survival of Atta sexdens rubropilos (Formicidae) via dietary intake (Torres et al., 2013). Plant extracts of Myrcia obtecta also demonstrated insecticidal activity for the control of S. zeamais (Coleoptera) (Vendramin, 2010).

\section{Conclusion}

In the phytochemical prospecting, saponins, steroids, triterpenoids, tannins, and flavonoids were identified in the plant extracts of $M$. oblongata. The extracts of M. oblongata showed activity for all tested microorganisms, except for the methanolic extract that showed no bactericidal activity for $P$. mirabilis and S. enteritidis. Hex, AcEt and AcOH extracts showed similar antioxidant activity to BHT (positive control); demonstrating important antioxidant potential. The essential oil and hexanic extract presented the highest mortality rates, above $95 \%$, on $A$. diaperinus larvae. The ethyl acetate, acetone, methanolic, and ethanolic extracts presented mortalities higher than $50 \%$. There was no mortality for the aqueous extract. The best adult lethality rate for $A$. diaperinus was for essential oil (92.5\%). The other treatments had mortality rates below $20 \%$.

\section{References}

ALI, L., SVENSSON, B., ALSANIUS, B.W. and OLSSON, M.E., 2011. Late season harvest and storage of Rubus berries-Major antioxidant and sugar levels. Scientia Horticulturae, vol. 129, no. 3, pp. 376381. http://dx.doi.org/10.1016/j.scienta.2011.03.047.

ARAÚJO, N.R.R., 2010. Avaliação in vitro da atividade antimicrobiana de extratos vegetais sobre microrganismos relacionados à lesão de mucosite oral. Belém: Universidade Federal do Pará. 100 p. Dissertação de Mestrado em Ciências Farmacêuticas.

ARTEAGA, F., BARRERO, A.F. and DOMINGO, V., 2009. Unusually cyclized triterpenes: occurrence, biosynthesis and chemical synthesis. Natural Product Reports, vol. 26, no. 1, pp. 115-134. http://dx.doi.org/10.1039/B801470C.

BONA, E.A.M., PINTO, F.G.S., FRUET, T.K., JORGE, T.C.M. and MOURA, A.C., 2014. Comparação de métodos para avaliação da atividade antimicrobiana e determinação da concentração inibitória mínima (CIM) de extratos vegetais aquosos e etanólicos. Arquivos do Instituto Biológico, vol. 81, no. 3, pp. 218-225. http://dx.doi. org/10.1590/1808-1657001192012.
BOSKOVIC, I., DUKIC, D.A., MASKOVIC, P., MANDIC, L. and PEROVIC, S., 2018. Phytochemical composition and antimicrobial, antioxidant and cytotoxic activities of Anchusa officinalis L. extracts. Biologia, vol. 73, no. 11, pp. 1035-1041. http://dx.doi. org/10.2478/s11756-018-0124-4.

BREWER, M.S., 2011. Natural Antioxidants: Sources, Compounds, Mechanisms of Action, and Potential Applications. Comprehensive Reviews in Food Science and Food Safety, vol. 10, no. 4, pp. 221247. http://dx.doi.org/10.1111/j.1541-4337.2011.00156.x.

BURT, S., 2004. Essential oils: their antibacterial properties and potential applications in foods - A review. International Journal of Food Microbiology, vol. 94, no. 3, pp. 223-253. http://dx.doi.org/10.1016/j.ijfoodmicro.2004.03.022. PMid:15246235.

CAMPOS, J.S. and FRANSSON, A.P.Z., 2011. Avaliação da atividade antioxidante do extrato aquoso de Lafoensia pacari A. ST-HIL. em emulsão não-iônica. Revista de Ciências Farmacêuticas Básica e Aplicada, vol. 32, pp. 363-368.

CARTELER, L.P., 2005. Erva-mate e atividade antioxidante. Santa Maria: Universidade Federal de Santa Maria. 99 p. Dissertação de Mestrado em Ciência e Tecnologia de Alimentos.

CARVALHO, A.A.T., SAMPAIO, M.C.C., SAMPAIO, F.C., MELO, A.F.M., SENA, K.X.F.R., CHIAPPETA, A.A. and HIGINO, J.S., 2002. Atividade antimicrobiana in vitro de extratos hidroalcoólicos de Psidium guajava L. sobre bactérias gram-negativas. Latin American Journal of Pharmacy, vol. 21, pp. 255-258.

CASTAÑEDA-OVANDO, A., PACHECO-HERNÁNDEZ, M.L., PÁEZHERNÁNDEZ, M.E., RODRÍGUES, J.A. and GALÁN-VIDAL, C.A., 2009. Chemical studies of anthocyanins: A review. Food Chemistry, vol. 113, no. 4, pp. 859-871. http://dx.doi.org/10.1016/j. foodchem.2008.09.001.

CAVANAGH, H.M.A. and WILKINSON, J.M., 2002. Biological activities of lavender essential oil. Phytotherapy Research, vol. 16, no. 4, pp. 301-308. http://dx.doi.org/10.1002/ptr.1103. PMid:12112282.

CERQUEIRA, M.D., MARQUES, E.J., MARTINS, D., ROQUE, N.F., CRUZ, F.G. and GUEDES, M.L.S., 2009. Variação sazonal da composição do óleo essencial de Myrcia salzmannii Berg. (Myrtaceae). Quimica Nova, vol. 32, no. 6, pp. 1544-1548. http://dx.doi. org/10.1590/S0100-40422009000600035.

CEYHAN, N., KESKIN, D. and UGUR, A., 2012. Antimicrobial activities of different extracts of eight plant species from four different family against some pathogenic microoorganisms. Journal of Food Agriculture and Environment, vol. 10, pp. 193-197.

CHAH, K.F., EZE, C.A., EMUELOSI, C.E. and ESIMONE, C.O., 2006. Antibacterial and wound healing properties of methanolic extracts of some Nigerian medicinal plants. Journal of Ethnopharmacology, vol. 104, no. 1-2, pp. 164-167. http://dx.doi. org/10.1016/j.jep.2005.08.070. PMid:16226414.

CLINICAL LABORATORY STANDARDS INSTITUTE - CLSI, 2007. Performance standards for antimicrobial susceptibility testing. Seventh Informational, vol. 35, no. 3, suppl., p. M100S25.

D'AOUST, J.Y. and MAURER, J. 2007. Food Microbiology. In: M.P. DOYLE and L.R. BEUCHAT, eds. Salmonella species, Washington: ASM Press, $219 \mathrm{p}$.

DOMINGUES, E.A., NAKAMURA, C.V., SOUZA, M.C., TEIXEIRA, T.S., PEIXOTO, J.L.B., SARRAGIOTTO, M.H. and VIDOTTI, G.J., 2010. Estudo fitoquímico e avaliação da toxicidade frente a Artemia salina e da atividade antimicrobiana de Calycorectes psidiiflorus (O. Berg) Sobral, Myrtaceae. Brazilian Journal of Pharmacognosy, vol. 20, no. 1, pp. 23-27. http://dx.doi.org/10.1590/S0102695X2010000100006. 
FERREIRA, I.C.S. and VARGAS, V.M.F., 1999. Mutagenicity of medicinal plant extracts in Salmonella/microsome assay. Phytotherapy Research, vol. 13, no. 5, pp. 397-400. http://dx.doi.org/10.1002/ (SICI)1099-1573(199908/09)13:5<397::AID-PTR473>3.0.CO;2-\# PMid:10441779.

GERSHENZON, J. and DUDAREVA, N., 2007. The function of terpene natural products in the natural world. Nature Chemical Biology, vol. 3, no. 7, pp. 408-414. http://dx.doi.org/10.1038/ nchembio.2007.5. PMid:17576428.

GRAHAM, H.N., 1992. Green tea composition, consumption, and polyphenol chemistry. Preventive Medicine, vol. 21, no. 3, pp. 334-350. http://dx.doi.org/10.1016/0091-7435(92)90041-F. PMid:1614995.

HERNÁNDEZ ÁNGEL, M. and PRIETO GONZÁLEZ, E.A., 1999. Plantas que contienen polifenoles: antioxidantes dentro del estilo de vida. Revista Cubana de Investigaciones Biomédicas, vol. 18, no. 1, pp. 12.

ISMAN, M.B., 2006. Botanical Insecticides, Deterrents, and Repellents in Modern Agriculture and an Increasingly Regulated World. Annual Review of Entomology, vol. 51, no. 1, pp. 45-66. http://dx.doi.org/10.1146/annurev.ento.51.110104.151146. PMid:16332203.

JAPP, A.K., BICHO, C.L. and SILVA, A.V.F., 2010. Importância e medidas de controle para Alphitobius diaperinus em aviários. Ciência Rural, vol. 40, no. 7, pp. 1668-1673. http://dx.doi.org/10.1590/ S0103-84782010005000114.

JUNG, P.H., SILVEIRA, A.C., NIERI, E.M., POTRICH, M., SILVA, E.R.L. and REFATTI, M., 2013. Atividade inseticida de Eugenia uniflora L. e Melia azedarach L. sobre Atta laevigata Smith. Floresta e Ambiente, vol. 20, no. 2, pp. 191-196. http://dx.doi.org/10.4322/ floram.2013.015.

KIM, E.-H., KIM, H.-K., CHOI, D.-H. and AHN, Y.-J., 2003. Acaricidal activity of clove bud oil compounds against Tyrophagus putrescentiae (Acari: acaridae). Applied Entomology and Zoology, vol. 38, no. 2, pp. 261-266. http://dx.doi.org/10.1303/ aez.2003.261.

LAMBKIN, T.A. and FURLONG, M.J., 2011. Metabolic Mechanisms Only Partially Explain Resistance to Pyrethroids in Australian Broiler House Populations of Lesser Mealworm (Coleoptera: tenebrionidae). Journal of Economic Entomology, vol. 104 no. 2, pp. 629-635. http://dx.doi.org/10.1603/EC10377. PMid:21510215.

LIMA, R.K., CARDOSO, M.G., SANTOS, C.D., MORAES, J.C., NÉRI, D.K.P. and NASCIMENTO, E.A., 2009. Caracterização química do óleo essencial de folhas de goiabeira (Psidium guajava L.) e seus efeitos no comportamento da lagartado-cartucho do milho Spodoptera frugiperda (J. E. Smith, 1797) (Lepidoptera: noctuidae). Ciência e Agrotecnologia, vol. 33, no. spe, pp. 1777-1781. http://dx.doi.org/10.1590/ S1413-70542009000700013.

MACEDO, I.T.F., BEVILAQUA, C.M.L., OLIVEIRA, L.M.B., CAMURÇAVASCONCELOS, A.L.F., VIEIRA, L.S. and AMÓRA, S.S.A., 2012. Evaluation of Eucalyptus citriodora essential oil on goat gastrointestinal nematodes. Revista Brasileira de Parasitologia Veterinária, vol. 20, no.3, pp. 223-227. http://dx.doi.org/10.1590/ S1984-29612011000300009. PMid:21961753.

MARCOMINI, A.M., ALVES, L.F.A., BONINI, A.K., MERTZ, N.R. and SANTOS, J.C., 2009. Atividade Inseticida De Extratos Vegetais E Do Óleo De Nim Sobre Adultos De Alphitobius Diaperinus Panzer (Coleoptera, Tenebrionidae). Arquivos do Instituto Biológico, vol. 76, pp. 413-420.

MATOS, F.J.A., 1997. Introdução à fitoquímica experimental. 2nd ed. Fortaleza: Fortaleza Edições UFC, 150 p.
MAZZONETTO, F. and VENDRAMIM, J.D., 2003. Efeito de pós de origem vegetal sobre Acanthoscelides obtectus (Say) (Coleoptera: Bruchidae) em Feijão Armazenado. Neotropical Entomology, vol. 32, no. 1, pp. 145-149. http://dx.doi.org/10.1590/S1519566X2003000100022.

MELO, E.A., LIMA, V.L.A.G., MACIEL, M.I.S., CAETANO, A.C.S. and LEAL, F.L.L., 2006. Polyphenol, Ascorbic acid and total carotenoid contents in common fruits and vegetables. Brazilian Journal of Food Technology, vol. 9, pp. 89-94.

MELO, E.D.A., INÊS, M., MACIEL, S., LÚCIA, V., GALVÃO, A. and JOSEFA, R., 2008. Capacidade antioxidante de frutas. Revista de Ciências Farmacêuticas, vol. 44, no. 2, pp. 193-201. http:// dx.doi.org/10.1590/S1516-93322008000200005.

NAIR, R. and CHANDA, S., 2007. In-vitro antimicrobial activity of Psidium guajava L. leaf extracts against clinically important pathogenic microbial strains. Brazilian Journal of Microbiology, vol. 38, no. 3, pp. 452-458. http://dx.doi.org/10.1590/S151783822007000300013.

NETTO, P., SPINOSA, H.S. and GORNIAK, S.L., 2005. Farmacologia aplicada à avicultura. 1st ed. São Paulo: Roca, 384 p.

PANDINI, J.A., GISELE, F., SCUR, M.C., FRANCISCO, L., ALVES, A. and MARTINS, C.C., 2015. Antimicrobial, insecticidal, and antioxidant activity of essential oil and extracts of Guarea kunthiana A. Juss. Journal of Medicinal Plants Research, vol. 9, no. 3, pp. 48-55. http://dx.doi.org/10.5897/JMPR2014.5551.

PAULA, J.A.M., PAULA, J.R., BARA, M.T.F., REZENDE, M.H. and FERREIRA, H.D., 2008. Estudo farmacognóstico das folhas de Pimenta pseudocaryophyllus (Gomes) L.R. Landrum - Myrtaceae. Brazilian Journal of Pharmacognosy, vol. 18, no. 2, pp. 265-278. http://dx.doi.org/10.1590/S0102-695X2008000200022.

PAULIQUEVIS, C.F. and FAVERO, S., 2015. Atividade insetistática de óleo essencial de Pothomorphe umbellata sobre Sitophilus zeamais. Revista Brasileira de Engenharia Agrícola e Ambiental, vol. 19, no. 12, pp. 1192-1196. http://dx.doi.org/10.1590/18071929/agriambi.v19n12p1192-1196.

PHAM-HUY, L.A., HE, H. and PHAM-HUY, C., 2008. Free radicals, antioxidants in disease and health. International Journal of Biomedical Science; IJBS, vol. 4, no. 2, pp. 89-96. PMid:23675073.

PRADO, G.P., 2007. Caracterização química e bioatividade do óleo essencial de Cunila angustifolia Benth (Lamiaceae) sobre Alphitobius diaperinus. Chapecó: Universidade Comunitária Regional de Chapecó, 60 p. Dissertação de mestrado em Ciências ambientais.

RATHI, J.M., ABSARA, S. and PRIYADHARSHINI, K., 2008. JEGATHAMBIKA, VQualitative phytochemical screening of some locally available insecticidal plants. Journal of Biopesticides, vol. 1, no. 1, pp. 52-54.

RAVEN, P.H., 2007. Biologia vegetal. Rio de Janeiro: Guanabara Koogan. 1637 p.

RICE-EVANS, C.A., MILLER, N.J. and PAGANGA, G., 1997. Antioxidant properties of phenolic compounds. Trends in Plant Science, vol. 2, no. 4, pp. 152-159. http://dx.doi.org/10.1016/S1360-1385(97)01018-2.

ROBERTS, S.C., 2007. Production and engineering of terpenoids in plant cell culture. Nature Chemical Biology, vol. 3, no. 7, pp. 387-395. http://dx.doi.org/10.1038/nchembio.2007.8. PMid: 17576426.

ROSA, C. S., VERAS, K. S., SILVA, P. R., LOPES NETO, J.J., CARDOSO, H. L. M., ALVES, L. P. L., BRITO, M. C. A., AMARAL, F. M. M., MAIA, J. G. S., MONTEIRO, O. S. and MORAES, D. F. C., 2016. Composição química e toxicidade frente Aedes aegypti L. e Artemia salina Leach do óleo essencial das folhas de Myrcia sylvatica (G. Mey.) DC. Revista Brasileira de Plantas Medicinais, vol. 18, no. 1, pp. 19-26. https://doi.org/10.1590/1983-084X/15_006 
SAKITA, M.N. and AGUIAR, O.T., 2006. Triagem fitoquímica e aspectos botânicos de Gomidesia affinis (CAMB.) LEGR. e Gomidesia spectabilis (DC.) BERG. O Biológico, vol. 68, pp. 817-820.

SALDANHA, L.L., 2013. Prospecção química e avaliação das atividades e alelopática de Myrcia bella Cambess. Botucatu: Universidade Estadual Paulista Júlio de Mesquita Filho. Dissertação de mestrado em Ciências Biológicas.

SÁNCHEZ-VARGAS, F.M., ABU-EL-HAIJA, M.A. and GÓMEZ-DUARTE, O.G., 2011. Salmonella infections: an update on epidemiology, management, and prevention. Travel Medicine and Infectious Disease, vol. 9, no. 6, pp. 263-277. http://dx.doi.org/10.1016/j. tmaid.2011.11.001. PMid:22118951.

SARTORATTO, A., MACHADO, A.L.M., DELARMELINA, C., FIGUEIRA, G.M., DUARTE, M.C.T. and REHDER, V.L.G., 2004. Composition and antimicrobial activity of essential oils from aromatic plants used in Brazil. Brazilian Journal of Microbiology, vol. 35, no. 4, pp. 275-280. http://dx.doi.org/10.1590/S1517-83822004000300001.

SAVARIS, M., LAMPERT, S., GARCIA, F.R.M., SABEDOT-BORDIN, S.M. and MOURA, N.F., 2012. Atividade inseticida de Cunila angustifolia sobre adultos de Acanthoscelides obtectus em laboratório. Ciencia y Tecnologia, vol. 5, no. 1, pp. 1-5. http:// dx.doi.org/10.18779/cyt.v5i1.121.

SCHERER, R., WAGNER, R., DUARTE, M.C.T. and GODOY, H.T., 2009. Composição e atividades antioxidante e antimicrobiana dos óleos essenciais de cravo-da-índia, citronela e palmarosa. Revista Brasileira de Plantas Medicinais, vol. 11, no. 4, pp. 442449. http://dx.doi.org/10.1590/S1516-05722009000400013.

SILVA, M.L.C., COSTA, R.S., SANTANA, A.S. and KOBLITZ, M.G.B., 2010. Compostos fenólicos, carotenóides e atividade antioxidante em produtos vegetais. Semina: Ciências Agrárias, vol. 31, no. 3, pp. 669-682. http://dx.doi.org/10.5433/1679-0359.2010v31n3p669.

SILVA, P.D., 2007. Estudo fitoquímico e avaliação das atividades antimicrobianas e antiparasitárias dos flavonóides isolados de Myrcia hiemalis (Myrtaceae). Bahia: Universidade Federal da Bahia. 106 p. Dissertação de mestrado em Química.

SIMÕES, C.M.O., SCHENKEL, E.P., GOSMAN, G., MELLO, J.C.P., MENTZ, L.A. and PETROVICK, P.R., 2004. Farmacognosia: Da planta ao medicamento. 5. ed. Porto Alegre: UFSC, 1102 p.

TAKAO, L.K., IMATOMI, M. and GUALTIERI, S.C.J., 2015. Antioxidant activity and phenolic content of leaf infusions of Myrtaceae species from Cerrado (Brazilian Savanna). Brazilian Journal of Biology = Revista Brasileira de Biologia, vol. 75, no. 4, pp. 948-952. http://dx.doi.org/10.1590/1519-6984.03314. PMid:26675912.
TAPONDIJOU, A.L., ADLER, C., FONTEM, D.A., BOUDA, H. and REICHMUTH, C., 2005. Bioactivities of cymol and essential oils of Cupressus sempervirens and Eucalyptus saligna against Sitophilus zeamais Motschulsky and Tribolium confusum du Val. Journal of Stored Products Research, vol. 41, no. 1, pp. 91-102. http://dx.doi.org/10.1016/j.jspr.2004.01.004.

TORRES, A.F., LASMAR, O., CARVALHO, G.A., SANTA-CECÍLIA, L.V.C., ZANETTI, R. and OLIVEIRA, D., 2013. Atividade inseticida de extratos de plantas no controle de formiga cortadeira, em cafeeiro. Coffee Science, vol. 8, pp. 371-378.

TURINA, A.V., NOLAN, M.V., ZYGADLO, J.A. and PERILLO, M.A., 2006. Natural terpenes : self-assembly and membrane partitioning. Biophysical Chemistry, vol. 122, no. 2, pp. 101-113. http://dx.doi. org/10.1016/j.bpc.2006.02.007. PMid:16563603.

VAN-ACKER, S.A.B.E., BERG, D.V.D., TROMP, M.N.J.L., GRIFFIOEN, D.H., BENNEKOM, W.P.V., VIJGH, W.J.F.V. and BAST, A.A.L.T., 1996. Strutural aspects of antioxidant activity of flavonoids. Free Radical Biology \& Medicine, vol. 20, no. 3, pp. 331-342. http:// dx.doi.org/10.1016/0891-5849(95)02047-0. PMid:8720903.

VENDRAMIN, E.J., 2010. [viewed 27 January 2020]. Modelagem, simulação e análise do processo de produção do biodiesel brasileiro [online]. Curitiba: Universidade Tecnológica Federal do Paraná. Dissertação de mestrado. Available from: http://repositorio.utfpr.edu.br/jspui/bitstream/1/1340/1/ CT_CPGEI_M_Vendramin\%2C Elton Joel_2010.pdf.

VIEIRA DA SILVA, B., BARREIRA, J.C.M. and OLIVEIRA, M.B.P.P., 2016. Natural phytochemicals and probiotics as bioactive ingredients for functional foods: Extraction, biochemistry and protected-delivery technologies. Trends in Food Science E Technology, vol. 50, pp. 144-158. http://dx.doi. org/10.1016/j.tifs.2015.12.007.

VOSS-RECH, D., KLEIN, C.S., TECHIO, V.H., SCHEUERMANN, G.N., RECH, G. and FIORENTIN, L., 2011. Antibacterial activity of vegetal extracts against serovars of Salmonella. Ciência Rural, vol. 41, no. 2, pp. 314-320. http://dx.doi.org/10.1590/S010384782011000200022.

WEBER, L.D., PINTO, F.G.S., SCUR, M.C., SOUZA, J.G.L., COSTA, W.F. and LEITE, C.W., 2014. Chemical composition and antimicrobial and antioxidant activity of essential oil and various plant extracts from Prunus myrtifolia (L.) Urb. African Journal of Agricultural Research, vol. 9, no. 9, pp. 846-853. http://dx.doi.org/10.5897/ AJAR2013.8260. 